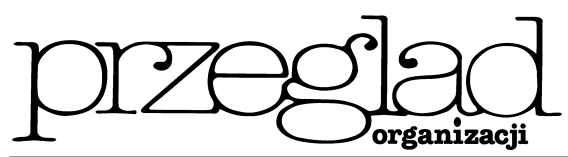

\title{
Ku systemowej teorii przewagi konkurencyjnej przedsiębiorstwa
}

https://doi.org/10.33141/po.2005.05.01

\author{
Wojciech Czakon
}

Przegląd Organizacji, Nr 5 (784), 2005, ss. 5-8 www.przegladorganizacji.pl Towarzystwo Naukowe Organizacji i Kierownictwa (TNOiK)

\section{Wprowadzenie}

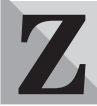

arządzanie strategiczne to dyscyplina wiedzy badająca niezwykle złożone obiekty, funkcjonujące w zmiennym otoczeniu. Celem badań jest wyjaśnienie różnorodności tych obiektów oraz efektów ich funkcjonowania po to, aby sformułować dyrektywy praktyczne. Wydaje się zatem, że zastosowanie podejścia systemowego powinno być oczywista koniecznością. Rzeczywiście, zarówno badacze, jak i praktycy deklarują traktowanie przedsiębiorstwa jako „zbioru elementów i powiązań pomiędzy nimi oraz pomiędzy nimi a otoczeniem".

Wyjaśnienia proponowane w zarządzaniu strategicznym wykazują jednak pewne luki, wobec których przyjęcie deklarowanego podejścia systemowego wydaje się niemożliwe. Szczególnie jaskrawa jest luka poznawcza w zakresie badań nad przewagą konkurencyjna.

Celem artykułu jest próba wykazania luki związanej z brakiem relacji pośród źródeł przewagi konkurencyjnej. Poszczególne źródła przewagi traktuje się tak, jakby były w pełni autonomiczne (zasoby, kompetencje, siły). Tymczasem pomiędzy tymi źródłami występują więzi. Szczególnie wyraziście ujawniają się one w tzw. sieciach międzyorganizacyjnych.

Autor podejmuje próbę wypełnienia tej luki poznawczej, wyłaniając relacyjne podejście do przewagi konkurencyjnej. Służą temu trzy części wywodu. Pierwsza precyzuje istotę luki poznawczej. Określa, dlaczego wyjaśnienia źródeł przewagi konkurencyjnej są niekompletne. Druga część wprowadza kategorię renty relacyjnej, krótko charakteryzując czynniki, które pozwalają ją osiągnaćc. Zamiast zakończenia proponuje się ramy badawcze podejścia relacyjnego.

\section{Niektóre luki teorii przewagi konkurencyjnej}

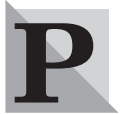

rzewaga konkurencyjna rozumiana jest jako trwałe osiąganie ponadprzeciętnej rentowności przez przedsiębiorstwo. Istnieją dwa główne podejścia do wyjaśnienia źródeł przewagi konkurencyjnej:

- podejście sektorowe, nazywane także podejściem Industrial Organization, odnosi się do propozycji najlepiej znanych przez dzieła M.E. Portera; stawia on tezę o uwarunkowaniu przewagi konkurencyjnej strukturą sektora, w którym przedsiębiorstwo funk-

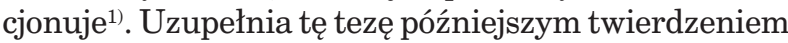

o wewnętrznych źródłach przewagi, tkwiących w systemie działań realizowanych przez przedsiębiorstwo, tj. w jego łańcuchu wartości ${ }^{2}$;

- podejście zasobowe, nazywane szerzej Resource Based View of the Firm. Stwierdza ono, że zasoby nie są ani jednolite, ani powszechnie dostępne, jak zakłada klasyczna mikroekonomia. Przeciwnie, są one zróżnicowane i rzadkie ${ }^{3)}$. W pewnych ich cechach, takich jak: rzadkość, imitowalność, trwałość itd. ${ }^{4}$ tkwi renta monopolistyczna. Umożliwia ona osiąganie ponadprzeciętnej rentowności.

Oba powyższe wyjaśnienia przedstawiono w dużym uproszczeniu ze względu na ograniczone ramy opracowania. Warto jednak podkreślić, że są one wobec siebie komplementarne. Oba podejścia powstały też w zbliżonym czasie. Wyjaśniają odrębne fragmenty problemu. Czy jednak spełniają postulat systemowy, w postaci wyjaśnienia opartego na zbiorze elementów oraz powiązań pomiędzy nimi? Otóż wydaje się, że nie. Oba te podejścia wyjaśniają źródła przewagi konkurencyjnej w sposób fragmentaryczny, a to ze względu na występowanie luki poznawczej niekompletności.

Luka niekompletności oznacza taki stan niewiedzy, w którym wyjaśnienie teoretyczne nie pokrywa w całości zachodzących zjawisk. Praktyka gospodarcza oczekuje odpowiedzi na pytanie o źródła przewagi przedsiębiorstwa na rynku. Oczekuje normatywnych wskazówek, jak osiągać przewagę. Badacze proponują odpowiedzi na to pytanie, podejmując także kwestie jej istoty oraz sposobu pomiaru. Powstaje zatem pytanie o przystawalność odpowiedzi do oczekiwań pytających. Ten fundamentalny problem sprowadzić można w istocie do oceny teorii przez praktyków. Ogólny problem przynosi różne stanowiska, wobec czego zachodzi potrzeba jego węższego sformułowania. Może nim być pytanie: czy teoria przewagi konkurencyjnej uwzględnia złożony i zmienny charakter wyjaśnianych zjawisk?

Tego typu pytanie można postawić większości wyjaśnień czy teorii naukowych. W przypadku przewagi konkurencyjnej pytanie nie tylko postawiono, ale także udzielono odpowiedzi na gruncie metod dedukcyjnych i empirycznych.

Podejście sektorowe zakłada uwarunkowanie rentowności przedsiębiorstwa czynnikami zewnętrznymi. Struktura sektora determinuje w tym podejściu pole sił oddziałujących na przedsiębiorstwo. W wyniku oddziaływania tych sił przedsiębiorstwo może 
osiągać niską lub wysoką rentowność. Dysponuje także środkami poprawy oraz ochrony tej rentowności. Zarzuty niekompletności w stosunku do tego podejścia obejmują dwa aspekty: naturę oddziaływań w polu sił sektora oraz wartość poznawczą wyjaśnienia przewagi konkurencyjnej na poziomie sektora.

Oddziaływania w polu sił sektora mają z założenia charakter antagonistyczny, wynikający ze sprzeczności celów uczestników sektora. Tymczasem antagonizm ten nie znajduje pełnego potwierdzenia w praktyce. Przedsiębiorstwa realizując swoje cele wybierają często związki kooperacyjne z innymi uczestnikami sektora, zarówno rywalami, jak i dostawcami czy klientami. Model sektorowy jest więc niekompletny ze względu na założenie „czystej” konkurencji, niezgodne ze stanem faktycznym.

Drugi aspekt niekompletności podejścia sektorowego wiąże się z jego weryfikacją praktyczną. Badania empiryczne przeprowadzone przez R. Rumelta ${ }^{5}$ pozwalają stwierdzić, że czynniki leżące po stronie przedsiębiorstwa (business specific) wyjaśniają sześć razy lepiej wariancję rentowności przedsiębiorstw niż czynniki sektorowe $^{6}$.

Podejście sektorowe nie wyjaśnia więc w sposób wyczerpujący zróżnicowania przedsiębiorstw ze względu na osiąganą w długim terminie rentowność.

Podejście zasobowe opiera się z kolei na założeniu, że posiadanie rzadkich zasobów stanowi źródło renty monopolistycznej, co skutkuje ponadprzeciętną rentownością przedsiębiorstwa. Inaczej niż w podejściu sektorowym koncentruje się uwagę badawczą na samym przedsiębiorstwie. Traktuje się je jako wiązkę zasobów. Klasyfikacje zasobów ulegają rozszerzeniu, np. o umiejętności, czy zasoby relacyjne ${ }^{7}$. W istocie jednak zasoby traktowane są jako autonomiczne źródła przewagi konkurencyjnej. Tymczasem pomiędzy nimi może występować efekt synergiczny w przedsiębiorstwie. J. Robins i M. Wiersema ${ }^{8)}$ badając wpływ kompozycji portfela na wyniki finansowe zdywersyfikowanego przedsiębiorstwa weryfikują siłę wyjaśniającą różnych modeli przewagi konkurencyjnej. Okazuje się, że model obejmujący więzi pomiędzy jednostkami przedsiębiorstwa wykazuje największą siłę wyjaśniającą. Oznacza to, że nie tylko zasoby jednostek biznesu, ale także ich powiązanie w synergicznym przedsiębiorstwie są źródłem przewagi konkurencyjnej.

Co więcej, więzi pomiędzy zasobami współdziałających przedsiębiorstw mogą stanowić nie tylko źródło kolejnego efektu synergicznego, ale wręcz warunek współpracy. Przykładem może być:

- w zakresie rzeczowych zasobów przedsiębiorstwa - lokalizacja zakładu produkcyjnego dostawcy w bezpośredniej bliskości zakładów klienta. Stanowi to powszechną praktykę w przemyśle motoryzacyjnym, a także w przemyśle energetycznym;

- w zakresie zasobów ludzkich - potrzeba dysponowania negocjatorami w przypadku współdziałania z sieciami hipermarketów, personelem o przygotowaniu finansowym w przypadku współpracy z bankami, czy kadrą inżynierską w przypadku współdziałania w projektach infrastrukturalnych; w zakresie zasobów informatycznych - dysponowanie systemem finansowo-księgowym współpracujacym z systemem bankowości elektronicznej znacznie obniża koszty księgowe, współpraca z przemysłem motoryzacyjnym wymaga stosowania platform EDI, a realizacja projektów inwestycyjnych - oprogramowania typu MsProject lub wręcz zintegrowanego systemu zarządzania klasy SAP;

- w zakresie zasobów organizacyjnych - posiadanie systemu zarządzania jakością certyfikowanego na zgodność z normami ISO serii 9001:2000, stanowi często warunek współpracy ${ }^{9)}$.

Określone powyżej więzi pomiędzy zasobami przedsiębiorstwa, a także pomiędzy nimi a otoczeniem, nie stanowią przedmiotu badań w podejściu zasobowym. Ze względu na wymóg systemowy podejście to jest zatem niekompletne.

Zauważyć wprawdzie można, w ramach rozwijania podejścia zasobowego, tendencję do ujmowania pewnych kategorii relacyjnych w jego ramach. Przykładem tych prób mogą być kategorie zasobów rynkowych oraz zasobów relacyjnych. Obie te kategorie odnoszą się do określonych więzi przedsiębiorstwa z podmiotami otoczenia. Jak jednak zauważa R. Burt ${ }^{10)}$ kategorie te wyraźnie różnią się od zasobów: rzeczowych, finansowych i ludzkich. Pojedynczy podmiot nie może ich bowiem posiadać, ani wykorzystywać, bez porozumienia z partnerami. Relacje istnieją ze względu na wszystkie zaangażowane strony. Nie są odrębną własnością którejkolwiek z nich.

Należy więc stwierdzić, że w zakresie źródeł leżących w przedsiębiorstwie oraz jego otoczeniu dotychczasowe podejścia, teorie przewagi konkurencyjnej wydają się zbliżać do kompletnego zbioru elementów. Jednocześnie stwierdzić trzeba, że powiązania pomiędzy tymi elementami są albo niekompletne, albo błędnie traktowane jako element. Lukom niekompletności towarzyszą pewne wysiłki zmierzające do ich wypełnienia. Zamiarem autora pozostaje przyczynienie się do tych wysiłków. Przyjmując tezę M. Peteraf ${ }^{11)}$ o monopolistycznym wyjaśnieniu ponadprzeciętnej rentowności można podjąć próbę określenia relacyjnych źródeł tego monopolu.

\section{Renta relacyjna źródłem przewagi konkurencyjnej}

W ymienione wyżej niedociągnięcia wyjaśnień przewagi konkurencyjnej ujawniają niektóre rodzaje relacji pomiędzy poszczególnymi elementami systemu przedsiębiorstwa. Pośród elementów wyróżniono: zasoby, ludzi, a także samo przedsiębiorstwo ze względu na sektorowy poziom analizy źródeł przewagi konkurencyjnej. Elementy te zdają się przyczyniać do osiągnięcia renty relacyjnej, a przez to również i przewagi konkurencyjnej, na trzy sposoby, tj. poprzez:

- wzrost efektywności ze względu na racjonalizację kosztów,

- przyspieszenie i doskonalenie procesów uczenia się,

- ułatwianie realizacji celów strategicznych. 
Przez rentę relacyjną rozumieć będziemy za J. Dyerem i H. Singhiem ${ }^{12)}$ „ponadprzeciętne przychody osiagane wspólnie przez przedsiębiorstwa uczestniczące we wzajemnej wymianie, których nie mogłyby one osiągnąc osobno, a które są możliwe do osiągnięcia wyłącznie poprzez idiosynkratyczny wkład konkretnych partnerów".

Racjonalizacja kosztów odwołuje się do trzech kategorii zjawisk: ograniczenia kosztów transakcyjnych, ograniczenia kosztów operacyjnych oraz poprawy elastyczności kosztów.

Ograniczenia kosztów transakcyjnych upatruje się w redukcji niepewności związanej z zachowaniem partnerów. Relacje społeczne istniejące pomiędzy ludźmi (zaufanie, wiarygodność, reputacja, normy społeczne), a także pomiędzy przedsiębiorstwami (wzajemne inwestycje w zasoby specyficzne oraz wzajemne przepływy strumieni pieniężnych) tworzą układ „wzajemnego zakładnika”, co osłabia skłonność do zachowań oportunistycznych $^{13)}$.

Ograniczanie kosztów operacyjnych zachodzi ze względu na dopasowanie zasobów rzeczowych, ludzkich i organizacyjnych współpracujących przedsiębiorstw. Zjawisko to zwane kospecjalizacją stanowi przedmiot wielu badań. Falsyfikują one twierdzenia teorii kosztów transakcyjnych, mówiące o wzroście ryzyka zachowań oportunistycznych w warunkach inwestycji w zasoby specyficzne. Przeprowadzone m.in. przez C. Donada ${ }^{14)}$ empiryczne badania w przemyśle motoryzacyjnym dowodzą, że dopasowanie zasobów do wymagań relacji z klientem przynosi korzyści konkurencyjne. Dotyczy to jednak inwestycji w zasoby potrzebne do utrzymania relacji, ale nie w fizyczne zasoby produkcyjne.

Poprawa elastyczności kosztów wiąże się z możliwością konfigurowania relacji przedsiębiorstwa ze względu na potrzeby rynku. W długim terminie posiadanie możliwości zmiany aktywów bez ponoszenia kosztów inwestycji oraz kosztów stałych z tytułu posiadania daje tzw. szybkość strategiczną (strategic agility). Aktywa te znajdują się bowiem w posiadaniu partnerów przedsiębiorstwa. Dostęp do nowych aktywów uzyskuje się poprzez zmianę partnerów. Występować tu jednak może dylemat lojalność - elastyczność. Oznacza on, że dążenie do ograniczania kosztów transakcyjnych zakłada wzajemną lojalność. Jej ograniczenie poprzez dowolne lub częste zmienianie partnerów wpływać może ujemnie na możliwość ograniczenia kosztów transakcyjnych.

Uczenie się stanowi w najnowszych osiągnięciach zarządzania strategicznego wpływowy nurt. Upowszechnia się pogląd o przejściu z gospodarki przemysłowej na gospodarkę opartą na wiedzy. Spotkać można nawet propozycje traktowania tego zjawiska jako rewolucji informacyjnej, analogicznie do rewolucji przemysłowej XIX wieku. Relacje przedsiębiorstwa wspierają zarówno pozyskiwanie istniejącej wiedzy, tworzenie nowej wiedzy, jak też dostęp do informacji.

Pozyskiwanie istniejacej wiedzy zachodzi w ramach struktury społecznej, w której przedsiębiorstwo jest osadzone. Występują w nim dobrze opisane efekty imitacji ${ }^{15)}$, tworzenia nowej wiedzy ${ }^{16)}$, czy ochrony wie- $\mathrm{dzy}^{17)}$. Jak metaforycznie napisał J. Owen-Smith i W. Powell ${ }^{18)}$ relacje przedsiębiorstwa są „kanałami i rurami" wiedzy, nie tylko przekazują ją pomiędzy podmiotami połączonymi relacją, ale także rozprzestrzeniają w otoczeniu (spillovers). Relacyjna renta ma swoje źródła we wiedzy rozumianej jako know-how, jak również we wiedzy rozumianej jako know-what. Dotyczy zatem nie tylko technologii, ale także rutynowych procedur współdziałania $\mathrm{z}$ innymi przedsiębiorstwami. Relacje przedsiębiorstwa $\mathrm{z}$ otoczeniem przyczyniają się do szybkiego rozprzestrzeniania wiedzy, ułatwiaja jej tworzenie. Stawiaja jednak problem ochrony własności intelektualnej.

Ułatwienie realizacji celów strategicznych to najszersza kategoria źródeł relacyjnej przewagi konkurencyjnej ${ }^{19)}$. Tworzenie relacji przedsiębiorstwa z otoczeniem stanowi narzędzie realizacji jego strategii $^{20)}$. Relacje przedsiębiorstwa stwarzają mu bowiem dostęp do kluczowych zasobów i zmniejszają ryzyko niepowodzenia. Przykładem może być opanowanie rynku odtwarzaczy wideo przez technologię VHS, możliwe dzięki zawarciu ogromnej liczby aliansów przez przedsiębiorstwo JVC. Umożliwiło to całkowitą dominację rynku i przesądziło o klęsce alternatywnej technologii Betamax, opracowanej przez Sony ${ }^{21}$. Kooperacja producentów doprowadziła do monopolizacji rynku, stwarzając możliwość czerpania renty monopolistycznej.

\section{Relacyjne podejście do przewagi konkurencyjnej}

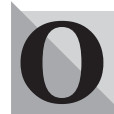

becny stan wiedzy o źródłach przewagi konkurencyjnej przedsiębiorstwa nie spełnia warunków stawianych podejściu systemowemu. Tym niemniej prowadzony od kilkunastu lat wysiłek badawczy przyczynił się w znacznym stopniu do opracowania szczegółowych odpowiedzi w zakresie relacyjnych uwarunkowań konkurencji. Oznacza to możliwość sformułowania zrębów podejścia relacyjnego, a szczególnie jego przedmiotu oraz metod badawczych. Osiągnięcie stanu dojrzałości teoretycznej w relacyjnym nurcie badań przewagi konkurencyjnej umożliwi opracowanie zintegrowanej, systemowej teorii.

Przedmiotem relacyjnego podejścia pozostają wszystkie więzi przedsiębiorstwa z otoczeniem. Metody badawcze pojawiające się w literaturze na przestrzeni ostatnich 20 lat koncentrują się na następujących ich aspektach:

- treści relacji, tj. podejmują wątek jej przedmiotu (wymiana towarów, informacji, uzgadnianie działań, wspólna realizacja działań), jej zakresu oraz czasu trwania (w tym częstotliwości), wykorzystując głównie metody opisowe;

- jakości, przy czym jakość relacji rozumie się jako szersze pojęcie niż zaufanie ${ }^{22}$, obejmuje bowiem „takie czynniki, jak: stopień zgodności kultur korporacyjnych i stylów podejmowania decyzji, zbieżność percepcji świata oraz inne cechy organizacji”. Na jakość relacji wpływ mają cztery grupy czynników: warunki wyjściowe, proces negocjacji, wzajemne doświadcze- 
nia w trakcie trwania relacji, zachowania partnerów poza relacją. Zastosowanie znajdują tu metody opisowe oraz badania ilościowe $\mathrm{z}$ wykorzystaniem rangowania wyników;

- struktury, gdzie wykorzystuje się dorobek socjologii w zakresie analizy sieciowej. Takie cechy jak: gęstość, centralność, luki strukturalne, siła powiązań, równorzędność strukturalna czy klastry, są mierzalnymi przedmiotami analizy ${ }^{23)}$. Zastosowanie znajduja tu metody ilościowe wykorzystujące wskaźniki struktury oraz teorię grafów.

Każdy z wymienionych aspektów stanowił treść badań i wielu odrębnych publikacji. Ich przedstawienie w tym miejscu służy do zasygnalizowania znacznego dorobku badawczego w wyłaniającym się podejściu relacyjnym.

Wydaje się, że tak zdefiniowane podejście relacyjne znacznie wykracza poza ramy badań nad aliansami przedsiębiorstw. Wiąże się to z: brakiem formalizacji wielu badanych więzi; uwzględnieniem relacji pomiędzy osobami, czyli kontekstu społecznego współdziałania przedsiębiorstw oraz potrzebą zastosowania narzędzi badania rozbudowanych struktur w postaci analizy sieciowej. Tym niemniej relacyjne podejście szeroko czerpie i buduje na dorobku badań nad aliansami przedsiębiorstw.

Relacyjne podejście zdaje się także wykraczać poza ramy analityczne kapitału społecznego. Choć stanowi on ważny element badań, to jednak istotny jest o tyle tylko, o ile przyczynia się do osiagnnięcia przewagi konkurencyjnej. Badany jest najczęściej z pozycji teorii kosztów transakcyjnych, a nie socjologii. Co więcej, źródła przewagi konkurencyjnej tkwią także w szczególnym dopasowaniu zasobów oraz procesach uczenia się.

Relacyjne podejście do przewagi konkurencyjnej wydaje się przejawiać cechy komplementarności wobec dotychczas dominujących wyjaśnień. Jego rozwój stanowi warunek sine qua non systemowej teorii przewagi konkurencyjnej.

dr Wojciech Czakon

Katedra Zarządzania Przedsiębiorstwem Akademia Ekonomiczna w Katowicach

\section{PRZYPISY}

1) M.E. PORTER, Strategia konkurencji, PWE, Warszawa 1996.

2) M.E. PORTER, Competitive Advantage - Creating and Sustaining Superior Performance, The Free Press, New York 1985.

3) J. PFEFFER, G. SALANCIK, The External Control of Organizations: A Resource Dependence Perspective, Harper \& Row, New York 1978.

4) Spotyka się kilka sposobów analizy zasobów, obejmujących od czterech do jedenastu cech: J. ROKITA. Zarzadzanie strategiczne, PWE, Warszawa 2005 s. 154, oraz M. BRATNICKI, Kompetencje przedsiębiorstwa, Placet, Warszawa 2000, s. 55-57.

5) R.P. RUMELT, How Much Does Industry Matter?, „Strategic Management Journal" 1991, vol. 12, nr 3, s. 167185.

6) Ściślej biorąc wyjaśniają one $46 \%$ wariancji wyników przedsiębiorstw wobec $8 \%$ wyjaśnień opartych na czynnikach sektorowych.
7) Patrz szerzej [w:] M. BRATNICKI, Kompetencje..., op.cit., s. $47-53$.

8) J. ROBINS, M.F. WIERSEMA, A Resource-Based Approach to the Multibusiness Firm: Empirical Analysis of Porfolio Interrelationships and Corporate Financial Performance, „Strategic Management Journal” 1995, vol. 16, nr 4, s. 277-299.

9) Wymienione przykłady stanowią egzemplifikację pojęcia zaczerpniętego z teorii kosztów transakcyjnych, a mianowicie zasobów specyficznych. Ściślej chodzi tu o zasoby specyficzne dla danej transakcji lub relacji z innymi podmiotami.

10) R.S. BURT, Structural Holes - The Social Structure of Competition, Harvard University Press, Cambridge, Massachussets 1992.

11) M.A. PETERAF, The Cornerstones of Competitive Advantage: a Resource Based View, ,Strategic Management Journal" 1993, vol. 14, s. 179-191.

12) Autorzy nie tylko definiują rentę relacyjną, ale także formułują cztery jej podstawowe źródła. Są nimi: inwestycje w zasoby specyficzne dla danej relacji, wymiana wiedzy, łączenie komplementarnych, ale rzadkich zasobów, niskie koszty transakcyjne. Patrz szerzej [w:] J. DYER, H. SINGH, The Relational View: Cooperative Strategy and Sources of Inteorganizational Competitive Advantage, „The Academy of Management Review” 1998, vol. 24, nr 4, s. 662.

13) C. JONES, W.S. HESTERLY, S.P. BORGATTI, A General Theory of Network Governance: Exchange Conditions and Social Mechanisms, „Academy of Management Review" 1997, vol. 22, nr 4, s. 926.

14) C. DONADA, Generating Cooperative Gain in a Vertical Partnership: A Supplier's Perspective, „Canadian Journal of Administrative Sciences 2002”, vol. 19, nr 2, s. 179-180.

15) Patrz szerzej np. [w:] J. GALASKIEWICZ, S. WASSERMAN, Mimetic Processes Within an Interorganizational Field, „Administrative Science Quarterly” 1989, vol. 34, nr 3, s. 454-479.

16) Szeroko opisane [w:] W. POWELL, K.W. KOPUT, L. SMITH-DOERR, Interorganizational Collaboration and the Locus of Innovation: Networks of Learning in Biotechnology, „Administrative Science Quarterly” 1996 , vol. 41, nr 1, s. 116-145.

17) Problemowi temu badania poświęcili m.in.: P. KALE, H. SINGH, H. PERLMUTTER, Learning and Protection of Proprietary Assets in Strategic Alliances: Building Relational Capital, „Strategic Management Journal” 2000, vol. 21, nr 3, s. 217-237.

18) J. OWEN-SMITH, W.W. POWELL, Knowledge Networks as Channels and Conduits: The Effects of Spillovers in the Boston Biotechnology Community, „Organization Science" 2004, vol. 15, nr 1, s. 5-21.

19) H. CHWISTECKA-DUDEK, W. SROKA, Alianse strategiczne. Problemy teorii $i$ dylematy praktyki. Wydawnictwo Profesjonalnej Szkoły Biznesu, Kraków 2000, s. 23.

20) Poglad taki wyraża m.in. B. GOMES-CASSARES, Do You Really Have an Alliance Strategy?, „Strategy \& Leadership" 1998, vol. 26 , nr 4, s. 6-11.

21) Szerzej na temat standardów technologicznych oraz uwarunkowań kooperacyjnych ich ustanawiania np. [w:] C. SHAPIRO, H.R. VARIAN, The Art of Standard Wars, „California Management Review” 1999, vol. 41, nr 2, s. $8-32$.

22) A. ARIŃO, J. de la TORRE, P.S. RING, Relational Quality: Managing Trust in Corporate Alliances, „California Management Review" 2001, vol. 44, nr 1, s. 109-131.

23) Patrz np. J. M. PODOLNY, T.E. STUART, M.T. HANNAN, Networks, Knowledge, and Niches: Competition in the Worldwide Semiconductor Industry, 1984-1991, „The American Journal of Sociology" 1996, vol. 102, nr 3, s. 659-689. 